\title{
MIEJSCA PAMIĘCI - DEFINIOWANIE POJĘCIA DLA OCHRONY ZABYTKÓW
}

Sites of Memory - defining the concept with regard to heritage protection

\section{Bogusław Szmygin ${ }^{*}$}

SUMMARY: Protection of memorial sites is becoming an increasingly important issue of heritage protection. Places of memory are places or historical objects which value arises primarily due to the meaning of their message/ symbol. In sites of memory, an intangible component is more important than an intangible component - it distinguishes its from other historical objects. In places of memory, the key feature is authenticity (understood broadly, according to the Document of Nara) while integrity is less important. Conservation theory should determine the rules for sites of memory taking into account their specificity in comparison with other monuments. This problem is presented in the article.

KEYWORDS: definitione, interpretation and protection of Sites of Memory

W ostatnich latach w międzynarodowym środowisku konserwatorskim problem miejsc pomięci stał się aktualny i ważny za sprawą dylematów, wobec których stanął ruch Światowego Dziedzictwa UNESCO ${ }^{1}$. Problem wpisywania miejsc pamięci na Listę Światowego Dziedzictwa nie był oczywiście nowy, gdyż już w 1979 roku - czyli w drugim roku tworzenia Listy - za dobro UNESCO uznano dawny nazistowski obóz koncentracyjny Auschwitz. Wniosek w sprawie tego wpisu złożył prof. Krzysztof Pawłowski podczas pierwszej sesji Komitetu Światowego Dziedzictwa, która odbyła się w Paryżu w 1977 roku² $^{2}$ Podczas dyskusji na temat kryteriów nominowania dóbr na Listę Światowe Dziedzictwo m.in. uznano, że taki status mogą również uzyskać miejsca, których przesłanie jest negatywne. Na tej podstawie dobrem UNESCO stał się

\footnotetext{
* Prof Bogusław Szmygin, Faculty of Civil Engineering and Architecture, Lublin University of Technology https://orcid.org/0000-0003-0629-4495
}

1 Między innymi w marcu 2017 roku we Florencji odbyła sie konferencja pt. Places of Memory - Protection, Conservation, Interpretation, zorganizowana przez dwa międzynarodowe komitety naukowe ICOMOS International Scientific Committee on Theory and Philosophy of Conservation and Restoration oraz International Scientific Committee on Interpretation and Presentation.

2 Podczas pierwszej sesji Komitetu Światowego Dziedzictwa prof. Krzysztof Pawłowski zaproponował w imieniu Polski wpisanie 5 dóbr - Stare Miasto w Krakowie, kopalnia w Wieliczce, odbudowane Stare Miasto w Warszawie, dawny obóz koncentracyjny Auschwitz-Birkenau oraz Puszcza Białowieska. Jednak podczas drugiej sesji Komitetu w 1978 roku zdecydowano, że w jednym roku z jednego kraju można na Listę wpisać tylko dwie nominacje. Dlatego wśród pierwszych 12 dóbr wpisanych na Listę znalazł się Kraków i Wieliczka, a obóz w Auschwitz i Puszcza Białowieska w roku 1979. - K. Pawłowski, 30 lat dziedzictwa światowego UNESCO, [w:] Wspótczesne problemy teorii konserwatorskiej Polsce, PKN ICOMOS i Politechnika Lubelska, Warszawa-Lublin 2008, ss. 93-99. 
dawny obóz zagłady, czyli miejsce, którego znaczenie wynika z rozegranych tam tragicznych wydarzeń, a nie prawie nieistotnej formy materialnej. Tym samym na Liście UNESCO pojawiła się kategoria miejsc pamięci, czego potwierdzeniem było wpisanie obozu w Auschwitz jedynie na podstawie kryterium VI (dotyczącego wartości niematerialnych) ${ }^{3}$.

Wpisanie dawnego obozu Auschwitz nie otworzyło jednak szeroko drzwi dla kolejnych tego typu nominacji. W 1979 roku Komitet Światowego Dziedzictwa przy okazji dyskusji na temat nominacji domu Edisona zdecydował bowiem, że Lista UNESCO nie powinna służyć upamiętnieniu znaczących postaci z poszczególnych krajów. Dlatego też przyjęto, że kryterium VI nie powinno być stasowane samodzielnie, czyli że nominowane miejsca pamięci powinny reprezentować również inne wartości (być nominowane na podstawie innych kryteriów). Ten system w praktyce funkcjonował, czego dowodem było wpisane na Listę zaledwie 12 dóbr tylko na podstawie kryterium VI (wśród ponad 800 dóbr kultury wpisanych do tej pory na Listę UNESCO). Warto przy tym podkreślić, że na temat stosowania kryterium VI dyskutowano jeszcze wielokrotnie, jednak nie zdecydowano się na jego inne sformułowanie, ani też na inną jego interpretację.

W ostatnich latach wzrosła jednak presja na wpisywanie miejsc pamięci i to w oparciu o kryterium VI. Symbolicznym przykładem był pomysł by na Liście UNESCO upamiętnić ludobójstwo, które w Rwandzie w 1994 roku pochłonęło milion ofiar. Ogromna skala tego dramatu nadawała tej propozycji specjalną rangę i wymagała starannej analizy. Równocześnie jednak specyfika tego przypadku - zadawniony konflikt dwóch narodów z wieloma dramatycznymi wydarzeniami, ponownie uświadomił Centrum Światowego Dziedzictwa, że casus Rwandy może rozpocząć niebezpieczny proces. Otóż Lista UNESCO może być wykorzystana do upamiętniania na forum międzynarodowym - pod wciąż znaczącym szyldem UNESCO - wielu niewygasłych konfliktów. A przede wszystkim może służyć sankcjonowaniu pewnej ich interpretacji. Jeżeli bowiem formalnie uznaje się zbrodnię i ofiarę, to tym samym wskazuje się sprawcę. Tymczasem w wielu przypadkach historia jest bardzo złożona i formalne jej rozstrzygnie jest ryzykowne. Oczywiście takie dylematy czasami trzeba rozstrzygać na forum międzynarodowym, ale nie musi w tym uczestniczyć Lista UNESCO.

3 Warunkiem pisania dobra kultury na Listę Światowego Dziedzictwa jest uznanie, że reprezentuje on tzw. wyjątkową uniwersalną wartość (OUV). Uznanie tej wartości polega na sprawdzeniu czy spełnione jest jedno z 6 kryteriów. Kryteria zdefiniowano w art.77 Wytycznych Roboczych. Kryterium VI stanowi, że dobro powinno być powiązane w sposób bezpośredni lub materialny $z$ wydarzeniami lub żywymi tradycjami, ideami, wierzeniami, dziełami artystycznymi lub literackimi o wyjątkowym uniwersalnym znaczeniu (Komitet jest zdania, że kryterium to powinno być stosowane raczej łącznie z innymi kryteriami).

4 Warto zwrócić uwagę, że jedna z ostatnich znaczących narad eksperckich na temat kryterium VI została zorganizowana przez Narodowy Instytut Dziedzictwa na zlecenie Centrum Światowego Dziedzictwa w Warszawie w 2012 roku. Między innymi pozostawiono sformułowanie kryterium VI, które po raz ostatni zredefiniowano w raku 2005. 
Miejsce pamięci - definiowanie pojeccia dla ochrony zabytków $\left[\square^{169}\right.$

\section{Raport - Interpretation of Sites of Memory}

W ostatnich latach dostrzeżono więc w Centrum Światowego Dziedzictwa dostrzeżono, że problem nominacji kolejnych miejsc pamięci będzie narastał. Postanowiono podjąć działania mające pomóc w ich rozwiązaniu. Uznano, że przede wszystkim trzeba podsumować obecny stan wiedzy na temat miejsc pamięci w kontekście Światowego Dziedzictwa. Powołano niewielką grupę roboczą, która miała zebrać i przeanalizować informacje na ten temat miejsc pamięci. Do współpracy zaproszono organizacje i instytucje zajmujące się tymi problemami na forum międzynarodowym, na czele z International Coalition of Sites of Conscience, organizacją zajmująca się grupą miejsc pamięci ${ }^{5}$. Efektem prac jest raport zatytułowany „Interpretation of Sites of Memory", który został upubliczniony w styczniu 2018 roku6.

Kilkudziesięciostronicowy raport zbiera i podsumowuje szereg informacji dotyczących miejsc pamięci oraz formułuje wnioski i rekomendacje, które warte są prezentacji.

Przede wszystkim w raporcie zwraca się uwagę na specyficzny kontekst, który stworzył warunki dla wzmożonego zainteresowania miejscami pamięci. Kluczowym czynnikiem jest bardzo istotna ewolucja pojęcia dziedzictwa, która systematycznie postępuje od lat powojennych. Pojęcie dziedzictwa wciąż jest poszerzane, może obejmować obecnie całe niewspółczesne środowisko kulturowe. Co bardzo istotne, pojęcie dziedzictwa jest coraz bardziej zorientowane na podmiot i bardzo szerokie spectrum wartości. W konsekwencji ważne są nie tylko obiektywne - materialne - cechy obiektu, ale też różne konotacje, interpretacje, znaczenia, wartości, które są mu przypisywane. Takie rozumienie dziedzictwa niewątpliwie sprzyja też uznaniu ważności grupy dóbr, o których znaczeniu decydują konotacje (wartości niematerialne); czyli właśnie miejsc pamięci.

Poszerzające podejście do dziedzictwa wiąże się z kolejnym podkreślonym w raporcie aspektem, którym jest wzrastające znaczenie interpretacji. W tradycyjnym konserwatorstwie podziały typologiczne zabytków były dokonywane przede wszystkim w oparciu o ich cechy materialne i funkcjonalne, a podziały te tworzyli specjaliści od ochrony dziedzictwa. Tymczasem obecnie coraz większe znaczenie mają dodatkowe znaczenia i wartości, np. duchowe (w raporcie operuje się pojęciem associative values) ${ }^{7}$. Co istotne, ta grupa wartości jest identyfikowana

5 International Coalition of Sites of Conscience jest globalną organizacją/siecią istniejącą od 1999 roku, która zrzesza muzea, miejsca pamięci i różnego rodzaju inicjatywy związane z upamiętnieniem wydarzeń i osób związanych z walką o szeroko rozumiane prawa człowieka. Koalicja zrzesza ponad 250 członków z pond 60 krajów, a jej działania polegają na szkoleniach, wsparciu finansowym i merytorycznym, sieciowaniu partnerów - https:// www.sitesofconscience.org/en/who-we-are/about-us/.

6 Raport „Interpretation of Sites of Memory” został przedstawiony 27 czerwca 2018 roku podczas 42 sesji Komitetu Światowego Dziedzictwa w ramach tzw. side event. Tekst raportu jest dostępny na stronie Centrum Światowego Dziedzictwa - https://whc.unesco.org/en/activities/933/.

7 W Raporcie przywołano też dokument Protected Landscapes and Spiritual Values opracowany przez IUCN, czyli organizację zajmującą się dziedzictwem naturalnym. W dokumencie tym wskazuje się, że również wiele chronionych dóbr natury ma rozbudowane znaczenia duchowe. 
przede wszystkim przez lokalne społeczności, które powinny uczestniczyć również w określaniu form ich ochrony. Szerokie możliwości interpretacji dziedzictwa i znaczenie udziału lokalnych społeczności w tym procesie zostały formalnie potwierdzone m.in. w deklaracji przyjętej podczas konferencji Nara+20 (2014). Rosnący udział interesariuszy w ochronie dziedzictwa tworzy też jednak dodatkowe problemy. Subiektywne i niematerialne wartości wskazywane przez interesariuszy trudno jest formalizować, a jest to konieczne od etapu dokumentacji, poprzez działania konserwatorskie aż do promocji i interpretacji.

W trzeciej części raportu zebrano informacje dotyczące bezpośrednio miejsc pamięci. Jako punkt wyjścia przyjęto i omówiono definicje proponowane przez Pierra Nora - najczęściej przywoływanego autora zajmującego się miejscami pamięci. W dalszej części wskazano jak szerokie jest pojęcie miejsca pamięci, wyliczając w kolejnych artykułach przykłady wydarzeń o bardzo różnym charakterze, które mogą być upamiętnione. Specjalną uwagę poświęcono miejscom upamiętniającym wydarzenia tragiczne. Dla ilustracji podano przykłady takich miejsc. Istotne w tej części raportu wydaje się zwrócenie uwagi na różnicę pomiędzy „miejscami pamięci” (Sites of Memory) a „miejscami sumienia” (Sites of Conscience), które są postrzegane odrębnie. Zwrócono też uwagę na różnice dzielące miejsca pamięci ze względu na wartość materialną - część miejsc pamięci ma bowiem również wartość jako budowle.

Czwarta część raportu została poświęcona interpretacji miejsc pamięci. Między innymi wymieniono szereg aspektów, które powinny być uwzględniane podczas szeroko rozumianego procesu interpretacji, w tym takie elementy jak badania, konserwacja, komunikacja, zarządzanie ${ }^{8}$. Zwrócono też uwagę na ciekawy problem różnic interpretacyjnych miejsc pamięci - wręczy skatalogowano różne pojęcia „prawdy” (truth), które można wyróżnić w interpretacji miejsc pamięć (par.75). Wskazano też kilkanaście różnych form przekazywania informacji/ interpretacji na temat miejsc pamięci.

W piątej części raportu przedstawiono problemy związane z nadawaniem miejscom pamięci określonego statusu. Jest to problem bardzo istotny, gdyż różne formy formalizacji miejsc pamięci mają istotny wpływ na jego interpretacje. W tym kontekście omówiono konsekwencje uznawania dóbr za Światowe Dziedzictwo UNESCO - na podstawie konwencji z 1972 roku, oraz wpisywania na Listę Dziedzictwa Niematerialnego UNESCO - na podstawie konwencji z roku 2003.

Raport kończą konkluzje i rekomendacje. Są one dosyć ogólnikowo i ostrożnie sformułowanie, co jest zgodnie z międzynarodowymi standardami tego typu dokumentów. Jednoznaczne rekomendacje dotyczą jedynie Listy Światowego Dziedzictwa, gdzie zaleca się ostrożne wpisywanie kolejnych miejsc pamięci. Proponuje się nawet by wprowadzić konkretnie regulacje dotyczące czasu, który powinien upłynąć od wydarzeń do ich upamiętnienia (50 lat lub 2 generacje), czy powoływanie międzynarodowych ekspertów akademickich, którzy mogą

8 Od kilkunastu lat formułowane są propozycje międzynarodowych standardów dotyczących badania, interpretacji i ochrony miejsc pamięci. Jako przykłady takich dokumentów można wskazać ICOMOS Charter for the Interpretation and Presentation of Cultural Heritage Sites defines interpretation (2008) czy Memory to Action: A Toolkit for Memorialization in Post-Conflict Societies, International Coalition of Sites of Conscience (2012). 
Miejsce pamięci - definiowanie pojeccia dla ochrony zabytków

obiektywniej ocenić proponowane nominacje (pkt.16i 17).

\section{Miejsce pamięci a zabytek}

Przywołany raport można uznać za swoiste podsumowanie stanu myślenia środowiska konserwatorskiego na temat miejsc pamięci, szczególnie w kontekście ich wpisywania na międzynarodowe listy UNESCO. Pozostawia on jednak obszary, które wymagają opracowania.

Z konserwatorskiego punktu widzenia konieczne wydaje się przede wszystkim określenie relacji pomiędzy miejscem pamięci a pojęciem dziedzictwa. Jest to problemem istotny dla praktyki konserwatorskiej. Jeżeli bowiem uzna się, że miejsce pamięci należy do obszaru dziedzictwa, to postępowanie z nim staje się terenem działań - nawet obowiązkiem konserwatora zabytków. A ta perspektywa może być niepokojąca. Należy bowiem zakładać, że wieloznaczność i symboliczny charakter miejsca pamięci tworzy problemy, do rozwiązywania których konserwatorzy zabytków mogą nie mieć kompetencji. To może mieć negatywne konsekwencje zarówno dla ochrony miejsc pamięci jak i wizerunku dyscypliny, który i tak nie jest zadawalający.

Konieczne wydaje się zatem doprecyzowanie pojęcia miejsca pamięci, określenie przypadków i granic, w których powinien zajmować się nim konserwator zabytków. Trzeba określić formy i zasady działania konserwatorskiego ujmujące specyfikę miejsca pamięci na tle innych grup typologicznych zabytków.

Konieczność odpowiedzi na te pytania wynika generalnie z potrzeb funkcjonowania systemu ochrony zabytków. W Polsce jednak ta kwestia ma dodatkowe znaczenie ze względu na problem utrzymywania śladów i upamiętnienia wydarzeń ważnych dla historii narodu polskiego, szczególnie z okresu II wojny światowej, również poza granicami kraju' . Miejsca takie jak hitlerowskie obozy zagłady od dawna określano jako miejsca pamięci, a jednocześnie traktowano i chroniono jako zabytki. Taki dualizm w miarę bezkonfliktowo funkcjonował w materialnie rozległych miejscach takich jak Auschwitz, Majdanek czy Stutthof. Nie może być jednak przeniesiony do tysięcy innych miejsc pamięci, w których są inne relacje komponentu materialnego i niematerialnego. I dla tych miejsc trzeba doprecyzować relacje pomiędzy zabytkiem a miejscem pamięci.

9 W internecie funkcjonuje na przykład strona zatytułowana Miejsca Pamięci Narodowej (http://www. miejscapamiecinarodowej.pl/). Zarejestrowano na niej blisko 1400 miejsc, które upamiętniają wydarzenia związane z historią Polski, poczynając od potopu szwedzkiego, aż do katastrofy smoleńskiej. W podobnym duchu była przygotowana ustawa sejmowa, która miała dotyczyć miejsc pamięci narodowej. Zgodnie z propozycja ustawy miejscami takimi są: groby lub cmentarze wojenne; nieruchomości lub obiekty budowlane albo jego pozostałości, upamiętniające postaci lub wydarzenia znaczące dla Narodu i Państwa Polskiego, a w szczególności pomnik, krzyż przydrożny, kapliczka, kopiec, inny obiekt lub przedmiot związany z wydarzeniami lub postaciami znaczącymi dla dziedzictwa Narodu i Państwa Polskiego, a w szczególności tablica pamiątkowa. 
Konserwatorzy zabytków muszą wiedzieć, czy miejsce pamięci jest elementem (podzbiorem) zbioru zabytków. W rozstrzygnięciu tej kwestii może być pomocne porównanie tych dwóch zbiorów. Nie jest to oczywiście proste, gdyż obydwa pojęcia są bardzo szerokie - co wynika z ich podmiotowego charakteru. Tym niemniej można je porównać, bazując na ich charakterystyce.

Dla konserwatorów zabytków mniej oczywiste jest pojęcie miejsca pamięci, tak więc to ono może stanowić punkt odniesienia. Większość piśmiennictwa na temat miejsc pamięci jako punkt wyjścia traktuje prace Pierra Nora, który definiował miejsce pamięci następująco:

A lieu de mémoire is any significant entity, whether material or non-material in nature, which by dint of human will or the work of time has become a symbolic element of the memorial heritage of any community (in this case, the French community).

Komentatorzy prac Nory podkreślają, że nie definiował on miejsc pamięci precyzyjne i konsekwentne. Dlatego miejsce pamięci mogą być rozumiane szeroko i obejmować m.in. archiwa, pomniki, muzea, obiekty historyczne, miejsca wydarzeń, postaci historyczne lub tylko symboliczne. Tym niemniej na podstawie tej definicji można stwierdzić, że miejsce pamięci to ważny byt materialny lub niematerialny, który na skutek ludzkich działań lub upływu czasu, stał się symbolicznym elementem pamięci o przeszłości dla pewnej społeczności. Ujmując kwestię w syntetyczny i upraszczający sposób można powiedzieć, że miejsce pamięci to byt, który funkcjonuje we wspólnej pamięci społeczności o jej historii.

$\mathrm{W}$ miejscu pamięci istotna jest zatem zbiorowa pamięć o wydarzeniach z przeszłości, natomiast nośniki tego historycznego komunikatu mają mniejsze znaczenie. Ten element wydaje się kluczowy w odróżnienia miejsca pamięci od zabytku rozumianego tradycyjnie, w którym najcenniejsza jest historyczna (autentyczna) forma i substancja - elementy decydujące o wartości dokumentu historycznego. W zabytku najcenniejszy jest on sam, podczas gdy w miejscu pamięci najcenniejszy jest komunikat.

Z faktu, że w miejscu pamięci ważny jest przede wszystkim historyczny komunikat, zachowany w pamięci społeczności, wynika też inny niż w przypadku zabytków stosunek do jego materialnego „nośnika”. Materialny „nośnik” komunikatu ważnego dla miejsca pamięci może też być współczesny. Jest to ważny element odróżniający miejsca pamięci od zabytków.

Aby uczytelnić różnice pomiędzy zabytkami a miejscami pamięci można dokonać zestawienia istotnych ich cech, dodając jeszcze dla porównania pomniki, które są jeszcze inną formą odwołania do historii. 
Charakterystyka porównawcza - zabytek, miejsce pamięci, pomnik

\begin{tabular}{|l|l|l|l|}
\hline Cecha & Zabytek & Miejsce Pamięci & Pomnik \\
\hline Typ dziedzictwa & Materialne & $\begin{array}{l}\text { Niematerialne } \\
\text { /możliwy nośnik } \\
\text { materialny/ }\end{array}$ & $\begin{array}{l}\text { Niematerialne } \\
\text { /konieczny nośnik } \\
\text { materialny/ }\end{array}$ \\
\hline $\begin{array}{l}\text { Kluczowa wartość/ } \\
\text { funkcja }\end{array}$ & $\begin{array}{l}\text { Dokument } \\
\text { historyczny }\end{array}$ & Upamiętnienie & Upamiętnienie \\
\hline $\begin{array}{l}\text { Informacja/ } \\
\text { komunikat }\end{array}$ & $\begin{array}{l}\text { Wieloznaczne } \\
\text { /niekonieczne jest } \\
\text { określanie/ }\end{array}$ & $\begin{array}{l}\text { Określony } \\
\text { i jednoznaczny }\end{array}$ & $\begin{array}{l}\text { Określony } \\
\text { i jednoznaczny }\end{array}$ \\
\hline Forma materialna & $\begin{array}{l}\text { Historyczna forma } \\
\text { i substancja }\end{array}$ & $\begin{array}{l}\text { Historyczna forma } \\
\text { i substancja lub } \\
\text { współczesna forma }\end{array}$ & $\begin{array}{l}\text { Współczesna/ } \\
\text { dowolna }\end{array}$ \\
\hline Integralność & Pożądana & $\begin{array}{l}\text { Niekonieczna/ } \\
\text { może być niewielki } \\
\text { fragment/ }\end{array}$ & Nie dotyczy \\
\hline Autentyzm & Konieczny & Pożądany & Nie dotyczy \\
\hline Lokalizacja & Historyczna & Historyczna lub inna & Historyczna lub inna \\
\hline
\end{tabular}

Porównanie przedstawionych w tabeli cech pokazuje, że trzy analizowane formy są w wielu aspektach odmienne. Różnice są na tyle istotne, że każda $\mathrm{z}$ form powinna być traktowana odrębnie. Oznacza to przede wszystkim, że należy określić inne zasady traktowania obiektów należących do każdej z tych trzech kategorii.

Zbiór miejsc pamięci i zbiór zabytków jest tożsamy tylko w pewnym zakresie. Z tego wynika, że konserwatorzy mając pełne kwalifikacje do zajmowania się zabytkami, miejscami pamięci powinni zajmować się tylko w zakresie, który pokrywa się ze zbiorem zabytków. W tym jednak zakresie miejsca pamięci powinny być pod konserwatorską jurysdykcją. Z punktu widzenia praktyki konserwatorskiej należy więc w zbiorze miejsc pamięci wydzielić zabytkowe elementy, które powinny być w obszarze odpowiedzialności konserwatora.

Porównanie miejsc pamięci i zabytków pozwala też na sformułowanie roboczej definicji, która określa owe zabytkowe miejsca pamięci.

A zatem: zabytkowe miejsce pamięci jest to miejsce i element historyczny (dlatego jest elementem zbioru dziedzictwa), który został uznany za nośnik i symbol, ważnego dla danej społeczności komunikatu.

Tak rozumiane miejsce pamięci jest materialnym dziedzictwem (w odróżnieniu od tych miejsc pamięci, gdzie materialny element nie jest dziedzictwem), które jest nośnikiem ważnego dziedzictwa niematerialnego.

Z zasady w miejscu pamięci komponent dziedzictwa niematerialnego (komunikat) ma 
większą wartość/znaczenie (w ocenie określającej go społeczności) niż komponent dziedzictwa materialnego.

Co ważne, wszystkie podane warunki są konieczne - powinny być spełnione jednocześnie.

Podsumowując można jeszcze zaproponować dopełniającą charakterystykę tych zabytkowych miejsc pamięci (lub ich elementów), którymi mogą i powinni zajmować się konserwatorzy zabytków.

- wartość zabytkowego miejsca pamięci wynika z wydarzenia (które się w tym miejscu odbyło) lub osoby (związanej z danym miejscem), a nie z cech/wartości materialnych tego miejsca (np. jako budowli, przestrzeni) - to $\mathrm{w}$ najistotniejszym stopniu odróżnia miejsce pamięci od innych grup typologicznych dziedzictwa;

- znaczenie/interpretacja/przesłanie konstytuujące zabytkowe miejsce pamięci jest jednoznacznie określone - dominuje nad innymi znaczeniami, których to miejsce może być również nośnikiem;

- zabytkowe miejsce pamięci musi być miejscem historycznym - autentyzm miejsca wydarzenia jest warunkiem koniecznym dla jego istnienia;

- historyczna forma materialna (czyli nośnik) zabytkowego miejsca pamięci może być skromna, niekompletna - integralność nie jest warunkiem koniecznym;

- koncepcja utrzymania formy/substancji zabytkowego miejsca pamięci pomimo ukierunkowana (nawet podporządkowana) utrwaleniu i przekazaniu znaczenia/komunikatu reprezentowanego przez miejsce pamięci, powinna spełniać rygory konserwatorskie. 
Miejsce pamięci - definiowanie pojęcia dla ochrony zabytków $\square$

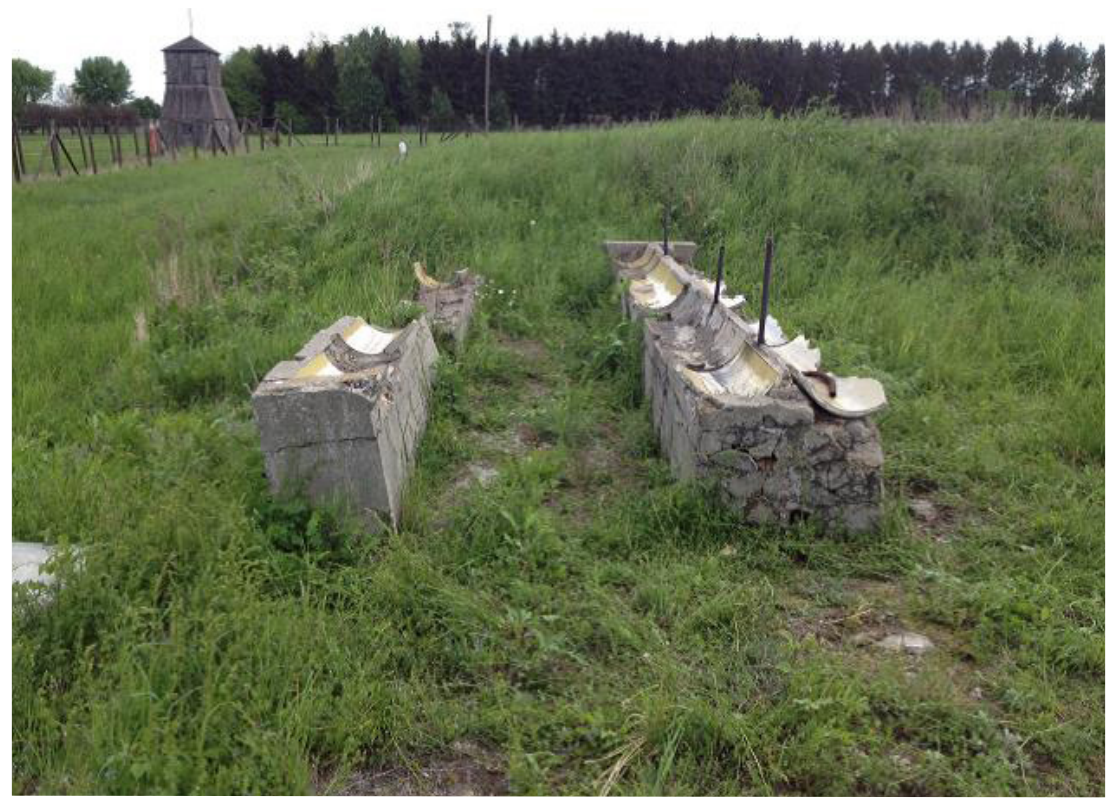

Fot.1. Zabytek i miejsce pamięci. Zniszczone postumenty umywalni - jedyna materialna pozostałość po barakach na polu dawnego niemieckiego obozu koncentracyjnego Majdanek (fot.B.Klimek)

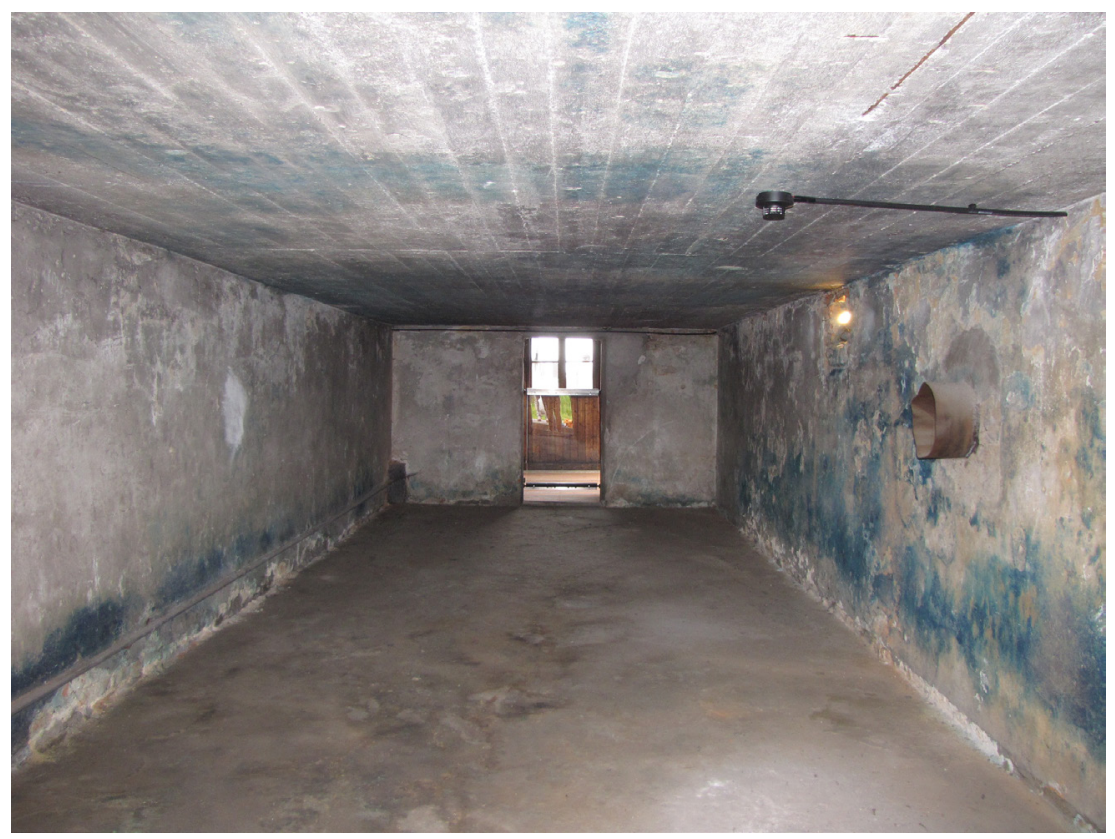

Fot.2. Zabytek i miejsce pamięci. Komora gazowa ze przebarwieniami tynku na skutek dzialania gazu cyklon B - dawny niemieckiego obozu koncentracyjnego Majdanek (fot.B.Klimek) 